\title{
Compelled to Be Ethical: Lessons Learned From the NCAA
}

\author{
Brent H. Kinghorn \\ Texas A\&M - Kingsville
}

Ethical scandals, particularly in the world of business are not a new phenomenon. However, the increase in scandals in the $21^{\text {st }}$ century provoked collective agents, namely the United States government, to undertake efforts to affect a change in the ethical behavior of all businesses regardless of industry. This research looks at the history of another collective agent's attempts to force a change in the target's ethical behavior. The long and involved history of one of the largest ethics programs, the National Collegiate Athletic Association (NCAA) provides an interesting perspective into the influence tactics of a collective agent to affect ethical behavior of a collective target.

Keywords: business ethics, NCAA, compulsion

\section{INTRODUCTION}

Ethical violations in the $21^{\text {st }}$ century have become a common fixture in the landscape of contemporary America and throughout the world. Violations take place from every level of government to all levels of private corporations. Scandals occurred in for-profit organizations to not-for-profit organizations. Indeed, it can be said that in the $21^{\text {st }}$ century few industries and few professions have been insusceptible to some form of shame in regards to their decisions.

The beginning of this century ushered in a number of corporate scandals in America. Recognizable corporations such as Adelphia, Arthur Anderson, Enron, PeopleSoft, RiteAid, Sunbeam, Tyco, Waste Management, WorldCom, and Xerox dominated public awareness of corporate greed and a general lack of accountability and responsibility. Such a high public awareness to these scandals also highlighted other issues in corporate America. Exorbitant earnings, excessive executive salaries, outsourcing of jobs, and financial institution failures also diminished the public trust.

These scandals, in their time, not only heightened awareness of certain ethical blunders but also eroded confidence in businesses. In 2002, as a response to the seemingly widespread corporate scandals, the United States Congress passed the Sarbanes-Oxley Act. When signing this Act into law, then President George W. Bush stressed the need for new standards of ethical behavior amongst organizations, particularly those actions of top managers and boards of directors responsible for overseeing the decisions and activities of those businesses. This complex law provided standards and penalties for unethical behavior, but still many executives found ways to subvert the law. Such subversive activities led to other attempts to force organizations to behave ethically. The latest of these, the Dodd-Frank Wall Street Reform and Consumer Protection Act passed in 2010, lauded as "a sweeping overhaul... on a scale not seen since the reforms that followed the Great Depression" (Obama, 2009) suggests that these efforts have not been overly effective. 
Such a suggestion gives rise to the question, can any institution influence others to undertake ethical behavior?

A determinant of any agent effectiveness is the ability to influence others to implement any directives or assignments (Yukl, 2002). The success of the agent to influence the target hinges on the tactics employed by the agent (Falbe \& Yukl, 1992). Multiple aspects of the use of influence tactics have been studied including the use of single tactics and combinations of tactics, the target of the influence tactic, relationship of agent and target, and the influence objective (e.g. Kipnis, Schmidt \& Wilkinson, 1980, Yukl \& Falbe, 1990, Falbe \& Yukl, 1992, Yukl, Lepsinger \& Lucia, 1992, Enns, Huff \& Higgins, 2003). However, little to no research has examined when the agent is a collective (such as a governmental body or the public) attempting to influence a target as diversified as "business organizations".

After a review of influence tactics, a historical view of such a collective agent's century long attempt to influence a diversified set of targets.

\section{INFLUENCE TACTICS}

Since the early 1980 's, research determined the effectiveness of influence tactics utilized by agents, in particular leaders, on targets, in particular subordinates, (see Yukl \& Chavez, 2002). The classification of these tactics, based on time frame and primary purpose, falls into three categories (Yukl \& Tracey, 1992). Proactive tactics attempt to influence the target to complete an activity immediately. Reactive tactics aim to resist influence from other agents or to modify current behavior to a more acceptable level. Impression management tactics endeavor to create a positive image and build closer relationships. These tactics may be used for other purposes, but the effectiveness in other purposes is diminished.

The outcomes of these influence tactics are commitment, compliance, or resistance (Yukl, 2002). Commitment occurs when the target internalizes agreement with the action or decision (Falbe \& Yukl, 1992). In addition, the target is enthusiastic about the action and likely to exercise initiative, unusual effort, and persistence to accomplish the task successfully. Compliance happens when the target is apathetic about the action or decision, makes minimal effort toward completion, and shows no initiative. Resistance results from opposition to the requested action in the form of refusals, arguments, delays, or attempts to nullify the request outright.

The success of the attempt to influence is determinant on the nature of the request as well as the immediate outcome. Commitment is more desirable than compliance when a complex request requires initiative, effort, and persistence for successful completion. In these situations, compliance is less desirable than commitment but still more desirable than resistance. Within simple or routine requests, compliance may be all that is needed to accomplish the target's objectives. In such conditions, compliance may be the most successful outcome given the agents desire.

While the outcomes of influence attempts, rely on several variables, such as type of tactic utilized, the projected objective, the relative power of agent and target, the relationship between agent and target, the expertise of the agent to exercise power, and the prior attitudes and perceptions of the target (Falbe \& Yukl, 1992), and therefore make the study of individual tactics and their outcomes difficult. Researchers employed a variety of methodologies to discover the effectiveness of these influence tactics including experiments (e.g. Yukl, Kim, \& Chavez, 1999), incidents (e.g. Yukl, Kim, \& Falbe, 1996), scenario studies (e.g. Fu \& Yukl, 2000), and surveys (e.g. Yukl \& Tracy, 1992). However, since no studies have attempted to look at the collective agent's influence tactics effects on a collective target, this study chose to review a similar scenario to uncover a beginning point.

\section{HISTORY OF THE NATIONAL COLLEGIATE ATHLETIC ASSOCIATION}

The National Collegiate Athletic Association (NCAA) provides an organized framework to provide college athletes opportunities (NCAA, 2021). The NCAA has almost 1100 universities and colleges as members. These members send representatives who serve on committees that propose rules and policies surrounding college sports. The members themselves ultimately decide which rules to adopt and implement. 
These rules consist of every aspect of the college sports from recruiting and compliance to academics and championships. Currently, the NCAA affects nearly half a million college athletes competing on almost 20,000 different teams that send more than 57,000 athletes to compete in more than 90 championships in 24 sports in 3 different divisions.

\section{0-1910}

Some of the earliest interschool athletic events in the United States involved elite regatta contests between Yale and Harvard Universities including one such event, sponsored by the then very powerful Elkins Railroad Line, in which Harvard sought to gain an undue advantage over their rival by employing the services of a coxswain who was not a student (Smith, 1987; Whitmer, 2015). Reports suggest that the coxswain in question received a suite of rooms at the dorm, free meals at the University club, $\$ 100$ scholarship, profits from the sale of programs, a commission on cigarettes sold in the city, and a 10-day vacation to Cuba. The president of Harvard at that time was concerned over the commercialization of college athletics stating that "lofty gate receipts from college athletics had turned amateur contests into major commercial spectacles" (Smith, 1991). The president of the Massachusetts Institute of Technology, in the same year, bemoaned that "if the movement shall continue at the same rate, it will soon be fairly a question whether the B.A. stand more for Bachelor of Arts or Bachelor of Athletics." Such realizations of both the undue cheating and loss of academic foundation led to the faculty oversight to provide a degree of regulation.

Despite the shift from student to faculty control and oversight, intercollegiate athletics remained underregulated, if not entirely unregulated, and a source of considerable concern. The first attempt to provide a foundation of ethical behavior in athletics was the Rowing Association of American Colleges in 1870, whose first sanctioned regatta was not attended by Yale University as they disputed their disqualification the previous year (New York Times, 1875). A second disputed race between Harvard and Yale four years later led to the demise of the association, which reverted compliance and regulation back into the lap of the faculty.

As other sports began to be contested between colleges and universities, concerns for the lack of regulation and the need to control the excesses of athletics increased (Smith, 1991). Baseball became popular in the post-Civil War era on most college campuses, but usually involved non-students and professionals as well as students (Crowley, 2006). The first collegiate game in 1859 featured Amherst playing under "Boston" rules beating Williams $73-32$. Football also employed similar members of their college teams, but the style of play provided the most difficulty. Football developed mass (or massmomentum) plays that were aided by the mass amounts of players on either side running into each other; one side trying to advance with the ball and the other trying to prevent that advance. The president of the University of California described football as "two rigid rampart-like lines of human flesh have been created, one of defense, the other of offense, and behind the latter is established a catapult to fire through a porthole opened in the offense ramparts a missile composed of four or five human bodies globulated about a carried football with a maximum initial velocity against the presumably weakest point in the opposing rampart." Such a description provides the background to countless injuries and many deaths. In fact, in 1905 alone, intercollegiate football accounted for over 18 deaths and 100 major injuries, prompting US president Theodore Roosevelt to call a White House conference to review college football rules (Smith, 1987).

Following the presidential review of college football rules, which major college football programs participated, deaths and injuries persisted. In 1906, the chancellor of New York University, Henry MacCracken, called for a meeting of the nation's major intercollegiate football programs to determine if football programs could be regulated or should be abolished (Smith, 1987). This well attended meeting led to the formation of a Rules Committee. President Roosevelt then had White House advisors meet with the newly formed Rules Committee (Smith, 1991). This concerted effort between major college football programs and the White House led to the formation of the Intercollegiate Athletic Association (IAA) with sixty-two original members. In 1910, the IAA was renamed the NCAA and the NCAA sought to formulate rules and regulations applied to many different intercollegiate sports. 
In the years prior to the formation of the NCAA, many attempts were made to combat the pressures to win, the commercialization of each sport, and to regulate and define rules for fairness and safety (Smith, 2000). These attempts, between 1840 and 1910, moved from loose student control to faculty oversight, from faculty oversight to small regional control, and finally to the development of a national entity.

\section{0-1970}

The early years of the NCAA saw little change in the landscape of intercollegiate athletics (Smith, 2000). While the NCAA did stretch its reach from simple rule making to the creation of national championships in several sports, student control, with some faculty oversight, was a dominating force in intercollegiate athletics. By the late 1920's, intercollegiate athletics were becoming an integral part of education as successful and entertaining programs developed and access to a college education eased. The increase in popularity, commercialization, and attention focused on regulation reached a crescendo when in 1929, the respected Carnegie Foundation for the Advancement of Education published a report regarding intercollegiate athletics with the finding:

\section{[A] change of values is needed in a field that is sodden with the commercial and the material and the vested interests that these forces have created. Commercialism in college athletics must be diminished and college sport must rise to a point where it is esteemed primarily and sincerely for the opportunities it affords to mature youth (Savage, 1929).}

The report also accused many intercollegiate athletic programs of recruiting athletes, giving them comfortable jobs, and paying them. The conclusion was that college athletics was pernicious to high school students and the nature and quality of high education.

While the NCAA made minor attempts to restructure rules to keep the integrity of intercollegiate athletics, those efforts were insufficient to keep pace with the outside commercialization and increased participation in these athletic events. After World War II, a dramatic increase in access to higher education, largely through government support of military personnel, led to a dramatic increase in interest in intercollegiate athletics. With the advent of the television, the presence of radios in most homes in the United States, and the broadcasting of intercollegiate athletic events, commercialization of intercollegiate athletics increased exponentially. These factors coupled with several gambling scandals and unethical recruiting extremes led the NCAA to set forth an abundance of new rules, resulting in an expansion of its governing authority (Smith, 1991).

In 1948, the NCAA formulated the "Sanity Code," with the design to reign in the exploitative practices in recruiting of potential athletes (Smith, 1987). In order to enforce this new decree, the NCAA formed the Constitutional Compliance Committee to interpret and examine possible violations. The Committee's only recourse for violations was expulsion, which was so severe that the Committee was reluctant to enforce its own ruling. In 1951, this committee was dissolved and the Committee on Infractions created and given broader permission for actions. This marks the point in time when the NCAA began to exercise the authority they had received from its members. The enforcement capacity of the NCAA increased annually throughout the 1950's and 1960's.

\section{1-1983}

With its enforcement capacity growing yearly, the NCAA began to be criticized for alleged unfairness of its enforcement of rules. The NCAA formed a committee to study the enforcement process and in 1973 adopted a new structure for more effective enforcement. The Committee on Infractions divided its investigative role from the prosecutorial role. In addition, the NCAA created divisions to reflect the competitive capacity of its members. However, when the NCAA was given greater authority to enforce the rules by penalizing schools directly and athletes, coaches, and administrators indirectly, criticism reached a fever pitch (Smith, 1991). In 1978, the United States House of Representatives Subcommittee on Oversight and Investigation held hearings to investigate the NCAA's enforcement processes and the alleged 
unfairness therein. While the NCAA did make changes in response to the criticisms leveled during those hearings, criticisms continued through the 1970's and 1980's.

The criticisms of the NCAA enforcement process were rather dichotomous during this time. On one hand, critique held that the NCAA inadequately responded to the increase in commercialization of intercollegiate athletics and all of its excesses, while on the other hand, critique was that the NCAA unfairly exercised its authority to punish its members for breaking the regulations. Another element of impact was the University and College Presidents. These men and women were also concerned with the NCAA operation for two distinct reasons (Smith, 2000). The first was that declining enrollments and increasing expenses were forcing administrators to view athletics less as a cost and more as a source of revenue and public relations. The second reason was an understanding that their reputations as presidents were tied to the success of the athletic program, which placed them in direct fear of the NCAA's enforcement authority.

\section{4-1999}

The difficult economic pressures of the 1980's were equally difficult for higher education. University presidents found themselves between the pressures of influential alumni and boards of regents, who demanded winning athletic programs, and faculty and staff that feared the rising commercialization of athletics would ruin academic values (Smith, 2000). These presidents sought the opportunity as a collective to take an active role in governance within the NCAA, so they formed the Presidents Commission. The presidents pursued many rule changes, particularly in the area of cost containment, but were largely unsuccessful (Smith, 1997). The presidents continued to assert their control until they finally changed the very governance structure of the NCAA by adding a new layer of governance to include an Executive Board and a Board of Directors at each of the various divisional levels.

During this period the NCAA defended itself against a couple of noteworthy lawsuits. In NCAA vs. Tarkanian, the United States Supreme Court held that the NCAA was not a government entity freeing it from the due process allegations brought from a penalized basketball coach, Jerry Tarkanian (Smith, 2000). This freedom from due process meant that legally the NCAA could operate with impunity, but that did nothing to quell the criticisms from the public about its enforcement process. Furthermore, in NCAA vs. Board of Regents, the United States Supreme Court held that the NCAA had violated antitrust laws (Smith, 2000). This defeat allowed schools to negotiate with outside sources to televise their football games. With this newfound freedom, a new division of schools occurred with schools with major football programs receiving more revenues than smaller schools a new unchecked imbalance occurred.

Utilizing their opportunity and public sentiment in the wake of these legal cases, the presidents took action to reform the enforcement policies of the NCAA. A special committee was formed to review the current practices and recommending new ones. Their report released in 1991 form the backbone of current enforcement policies, which are constantly updated (Smith, 2000). The outcomes of such updates have been focused largely on governance and economic issues, but there were some efforts to enhance academic integrity and revitalize the faculty oversight of athletics (Smith, 2000).

\section{Recent}

The NCAA still battles criticism of its policies. Recent years have seen an increase in court cases generated from the athletes themselves. In the case of White, et al. vs. NCAA, student-athletes argued that the NCAA limit on scholarship amounts was a violation of federal antitrust laws (Paskus, 2010). If the NCAA had not limited the scholarship to cost of attendance amounts then the schools would be able to offer any amount that the school desired. In 2014, players from a major college football program alleged the NCAA to be an unlawful cartel, charging it with illegally restricting the earning power of athletes by capping the values of the scholarships they received (Strauss, 2015). An athlete sued the university after having his scholarship revoked. The university claimed that the athlete violated NCAA regulations and the university took preemptive action to avoid punishment (Morey, 2018).

The NCAA reports that in 2019 , in the top division alone more than 700 possible violations were reported, 250 of those reports were investigated, and 94 allegations of wrongdoing were processed (NCAA, 2020a). The allegations begin the resolution process when punishments are handed out. In 2019, the NCAA 
also added a new enforcement process known as the Independent Accountability Resolution Process (NCAA, 2020b). This new process allows for an offending university or college to choose the method of resolution for their violations. This process positions the university or college as a collaborator in their punishments. Ultimately, a new Infractions Appeals Committee has approval of the outcomes.

\section{CONCLUSIONS}

This brief history of the NCAA provides a number of notable insights into ethical behavior. A few of those insights are expounded. First, since ethical behavior is not a quantifiable outcome, rules and regulations attempt to induce ethical behavior. The individual is the target of influence tactics (Yukl, 2002), but the collective cannot effectively persuade ethical behavior by compelling through rules and regulations. The NCAA's annual defining and redefining what constitutes correct behavior suggests that members attempt to find different means of getting ahead than what the rules and regulations protect. These attempts to imbalance the competitive scales in one member's highlight the failure of the collective to influence an individual's behavior. After more than 100 years of regulations, members of the NCAA still break the rules. In fact, the number of lawsuits waged against the NCAA in the last 20 years suggests an outright deviance of those efforts.

Next, definition of rules and regulations mutate from legislation through investigation to punishment and involves an increase in overhead in the form of administration and personnel. In 1910, the NCAA had five full-time employees (McGuff. 1973). Today, the NCAA has 500 full-time employees, but also utilizes nearly 5,000 volunteers to provide governance (NCAA, 2021). The current operating budget of management for the NCAA is $\$ 40$ million (NCAA, 2021), which is also an increase from the three room, no air-conditioned office and five employee beginnings of the NCAA. Such an increase coincides with an increase from simple creation of rules and regulations to punitive and oversight responsibilities. Any other collective attempt to prompt ethical behavior would also see an increase in the administrative costs.

Finally, a governing collective provides compliance outcomes but not the more effective commitment outcomes (Yukl \& Falbe, 1990). As suggested earlier, this is perhaps because the collective cannot use the correct influence tactics with the individual. A first step, in not simply complying with the rules and regulations, may be simply becoming aware of all stakeholders in an issue and analyzing the full spectrum of choices available (Jones, 1991). Recent lawsuits involving the NCAA suggest that some think that this body is behaving without regard for their interests, but the lawsuits suggest that the individual is not paying attention to the larger stakeholders outside of themselves. The Association to Advance Collegiate Schools of Business (AACSB), the accrediting body of business schools around the world formed a task force with an emphasis on ethics education (AACSB, 2004). This task force sought to include ethics education as the part of any business degree curricula. Such efforts increase the individual ethical awareness and might be able to increase the individual ethical behavior within the bigger organization. This is the place that focus should be paid, to education, rather than legislating behavior. Certainly, 100 years of NCAA attempts to promote ethical behavior suggest such a conclusion.

\section{REFERENCES}

AACSB. (2004). Ethics Education in Business Schools. AACSB International: Tampa, FL.

Case, T., Dosier, L., Murkinson, G., \& Keys, B. (1988). How managers influence superiors: A study of upward influence tactics. Leadership and Organizational Development Journal, 9(4), 25-31.

Crowley, N. (2006). In the Arena: The NCAA's First Century (1st ed.) National Collegiate Athletic Association Publishing:

Enns, H., Huff, S., \& Higgins, C. (2003). CIO Lateral Influence Behaviors: Gaining Peers' Commitment to Strategic Information Systems. MIS Quarterly, 27(1), 155-176.

Falbe, C., \& Yukl, G. (1992). Consequences for Managers of Using Single Influence Tactics and Combinations of Tactics. Academy of Management Journal, 35(3), 638-652. 
Jones, T. (1991). Ethical decision making by individuals in organizations: An issue-contingent model. Academy of Management Review, 16(1), 366-395.

Kipnis, D., Schmidt, S., \& Wilkinson, I. (1980). Intraorganizational Influence Tactics: Explorations in Getting One's Way. Journal of Applied Psychology, 65(4), 440-452.

McGuff, J. (1973). Growth of NCAA apparent; but optimism still abounds. NCAA News. Retrieved May 3, 2021, from https://wayback.archiveit.org/all/20140916223210/http://fs.ncaa.org/Docs/NCAANewsArchive/1973/19730615.pdf

Morey, A. (2018). Former University of Central Florida kicker scores courtroom win in YouTube case.

NCAA. (2020a). Executive Summary, NCAA Division 1 Infractions 2019 - 2020 Annual Report. Retrieved April 6, 2021, from https://iarpcc.org/wp-content/uploads/2020/11/2019-20Infractions-Annual-Report-Exec-Summary-1.pdf

NCAA. (2020b). NCAA Division 1 Infractions 2019 - 2020 Annual Report. Retrieved from April 6, 2021, https://iarpcc.org/wp-content/uploads/2020/11/2019-20-Infractions-Annual-Report-Full-Report1.pdf

NCAA. (2021). What is the NCAA? Retrieved January 23, 2021, from https://www.ncaa.org/about/resources/media-center/ncaa-101/what-ncaa

New York Times. (1875, July 15). Record of the college regattas: From the Winnepesoagee Contest in 1852 up to yesterday.

Obama, B. (2010). Remarks by the President on $21^{\text {st }}$ Century Financial Regulatory Reform. The White House, June 17, 2009. Retrieved from June 18, 2019, $\mathrm{http}: / /$ whitehouse.gov/the press_office/Remarks-of-the-President-on-Regulatory-Reform/

Paskus, T. (2010). NCAA Division I Academic Progress Rate. Interuniversity Consortium for Political and Social Research. (Report).

Savage, H. (1929). American College Athletics (p.240). New York, NY: The Carnegie Foundation for the Advancement of Teaching, Bulletin No. 23.

Smith, R. (1987). The National Collegiate Athletic Association's death penalty: How educators punish themselves and others. Indiana Law Journal, 62(4), 985-1059.

Smith, R. (1991). Little ado about something: Playing games with the reform of big-time athletics. Capital University Law Review, 567, 569-570.

Smith, R. (2000). A brief history of the National Collegiate Athletic Association's Role in Regulating Intercollegiate Athletics. Marquette Sports Law Review, 11(1), 9-22.

Strauss, B. (2015). N.L.R.B. Rejects Northwestern Football Players' Union Bid. Retrieved May 23, 2021, from https://www.nytimes.com/2015/08/18/sports/ncaafootball/nlrb-says-northwestern-footballplayers-cannot-unionize.html

Whitmer, M. (2015). Harvard and Yale crews celebrate the 150th Boat Race. Boston Globe. Retrieved March 25, 2021.

Yukl, G. (2002). Leadership in Organizations (5th ed.). Upper Saddle River, NJ: Prentice Hall.

Yukl, G., \& Chavez, C. (2002). Influence tactics and leader effectiveness. In L. Neider \& C. Schriesheim (Eds.), Leadership (pp. 139-165). Greenwich, CT: Information Age.

Yukl, G., \& Falbe, C. (1990). Influence Tactics and Objectives in Upward, Downward, and Lateral Influence Attempts. Journal of Applied Psychology, 75(2), 132-140.

Yukl, G., \& Tracey, B. (1992). Consequences of influence tactics used with subordinates, peers, and the boss. Journal of Applied Psychology, 77, 525-535.

Yukl, G., Lepsinger, R., \& Lucia, T. (1992). In K. Clark, M. Clark, \& D. Campbell (Eds.), The Impact of Leadership (pp. 417-427). Center for Creative Leadership, Greensboro, NC. 